\title{
Regulation of amphiregulin and epiregulin expression in human colonic subepithelial myofibroblasts
}

\author{
OSAMU INATOMI, AKIRA ANDOH, YUHKI YAGI, SHIGEKI BAMBA, \\ TOMOYUKI TSUJIKAWA and YOSHIHIDE FUJIYAMA
}

\author{
Department of Internal Medicine, Shiga University of Medical Science, Seta-Tukinowa, Otsu 520-2192, Japan
}

Received March 10, 2006; Accepted May 2, 2006

\begin{abstract}
Amphiregulin and epiregulin belong to the epidermal growth factor (EGF) family, and act as mitogenic stimulators via binding to EGF receptors (EGFRs). Amphiregulin and epiregulin are thought to play a role in regenerative responses in the gastrointestinal tract. In this study, we investigated secretion of amphiregulin and epiregulin in human colonic subepithelial myofibroblasts (SEMFs). The mRNA expression and protein secretion of amphiregulin and epiregulin were evaluated by Northern blotting and Western blotting, respectively. The trophic effects of amphiregulin and epiregulin on SEMFs were analyzed by MTT assays. Amphiregulin and epiregulin mRNAs were not detected in unstimulated SEMFs. Among the various cytokines and growth factors, interleukin-1 1 , tumor necrosis factor- $\alpha$, and EGF strongly induced amphiregulin and epiregulin mRNA expression. These responses were markedly reduced by AG1478, a specific inhibitor of EGF receptor tyrosine kinases. Amphiregulin and epiregulin secretion were also detected at the protein level. MTT assays demonstrated that amphiregulin and epiregulin stimulate the proliferation of SEMFs. We demonstrated expression of amphiregulin and epiregulin in SEMFs. Amphiregulin and epiregulin may play an important role in the mechanism underlying wound healing in damaged colonic mucosa.
\end{abstract}

\section{Introduction}

Amphiregulin and epiregulin belong to the epidermal growth factor (EGF) family which includes EGF, transforming growth factor (TGF)- $\alpha$, heparin-binding (HB)-EGF, betacellulin, and various heregulins. These factors mediate biological functions of epithelial and mesenchymal cells through the EGF receptors

Correspondence to: Dr Akira Andoh, Department of Internal Medicine, Shiga University of Medical Science, Seta Tukinowa, Otsu 520-2192, Japan

Key words: amphiregulin, epiregulin, colonic subepithelial myofibroblasts
(EGFRs) (1). Several studies have demonstrated that the EGF family and the EGFR signaling pathway play a crucial role in the regenerative response of mucosal damage in the gastrointestinal tracts (2-4).

Amphiregulin is a 252 amino-acid transmembrane glycoprotein, and was originally isolated from human breast carcinoma cell line MCF-7 (5). The mRNA expression for amphiregulin can be detected in a variety of carcinoma cell lines, and in non-transformed epithelial and mesenchymal cells from the colon, stomach, lung, breast, ovary and kidney (6). Amphiregulin stimulates the proliferation of keratinocytes, fibroblasts and epithelial cells (7-9). In some carcinoma cell lines, amphiregulin stimulates their proliferation through autocrine mechanisms $(10,11)$. Beales et al demonstrated that amphiregulin stimulates proliferation of the gastric mucosa (12).

Epiregulin is a 46 amino-acid active protein, and was initially purified from the conditioned medium of the fibroblastlike cell line NIH3T3/T7 (13). Epiregulin stimulates the proliferation of non-transformed fibroblasts, hepatocytes, smooth muscle cells, and keratinocytes, but inhibits the growth of several tumor-derived epithelial cell lines (14-16). Lee et al reported that epiregulin null mice are highly susceptible to intestinal damage caused by oral administration of dextran sulfate sodium (17).

In this study, we evaluated secretion of amphiregulin and epiregulin from human colonic subepithelial myofibroblasts (SEMFs). SEMFs play a critical role in the pathophysiological processes involved in inflammation and wound healing in the intestine (18-22). We found that proinflammatory cytokines such as interleukin (IL)-1ß, tumor necrosis factor (TNF)- $\alpha$, and EGF were strong inducers of amphiregulin and epiregulin in colonic SEMFs. Furthermore, amphiregulin and epiregulin act as autocrine growth factors for colonic SEMFs.

\section{Materials and methods}

Reagents. Recombinant human IL-1ß, TNF- $\alpha$, amphiregulin and epiregulin were obtained from R\&D Systems (Minneapolis, $\mathrm{MN}$ ). All other cytokines and growth factors were purchased from PeproTech (Rocky Hill, NJ). The EGF receptor tyrosine kinase inhibitor (AG1478) was purchased from Calbiochem (San Diego, CA). 3-[4,5-dimethylthiazol-2-yl]-2,5diphenyltetrazolium bromide (MTT) was purchased from Sigma (St. Louis, MO). 
Culture of human colonic myofibroblasts. Primary cultures of intestinal SEMFs were prepared according to the method reported by Mahida et al (18). The characteristics of these cells have been described in our previous report (23-25). The cells were cultured in DMEM containing $10 \%$ FBS. The studies were performed on passages 2-6 of myofibroblasts isolated from 3 resection specimens.

Immunoprecipitation and Western blotting. Conditioned medium $(5 \mathrm{ml})$ was incubated with $2 \mu \mathrm{g} / \mathrm{ml}$ of antiamphiregulin rabbit IgG (Chemicon, Temecula, CA) or epiregulin goat IgG (R\&D Systems, Minneapolis, MN) for $1 \mathrm{~h}$, and then $20 \mu \mathrm{l}$ of Protein G-Sepharose beads (Amersham, Arlington Heights, IL) was added to the reaction mixture. After a 16-h incubation, beads were suspended in $20 \mu 1$ of loading buffer and separated by $16 \%$ of sodium dodecylsulfatepolyacrylamide gel electrophoresis (SDS-PAGE) under reducing conditions. SDS PAGE gels were then electrophoretically transferred onto nitrocellulose membranes. Membranes were soaked with $200 \mathrm{ng} / \mathrm{ml}$ of anti-amphiregulin or epiregulin goat $\operatorname{IgG}$ (R\&D Systems) for $1 \mathrm{~h}$, followed by incubation with peroxidase-conjugated anti-goat IgG (Santa Cruz Biotechnology, Santa Cruz, CA). The detection was carried out by means of ECL kit (Amersham).

Reverse-transcription polymerase chain reactions. The mRNA expression for EGFR, ERBB2, ERBB3 and ERBB4 was assessed by reverse-transcription polymerase chain reaction (RT-PCR) analyses (26). PCR products were ligated into TA cloning vectors (Promega, Madison, WI) and sequenced. Primers specific for human EGFR were as follows: 5':TGAT GGCCAGCGTGGACAACC [corresponding to nucleotides 2416-2436 (27)] and 3':CATGGTATTCTTTCTCTTCCGCA (nucleotides 2711-2733). Primers for ERBB2 were as follows: 5':GGCTGCTGGACATTGACGAG [nucleotides 2777-2796 (28)] and 3':GGGGCTGGGGCAGCCGCTC (nucleotides 2989-3007). Primers for ERBB3 were as follows: 5':GGAGT ACAAATTGCCAAGGGAA [nucleotides 2636-2657 (29)] and 3':CAGGTCTGGCAAGTATGGAT (nucleotides 29422962). Primers for ERBB4 were as follows: 5 ':CTCTGATCAT GGCAAGTATGGAT [nucleotides 2339-2361 (30)] and 3':CA TTGTATTCTTTTTCATCTCCTTC (nucleotides 2638-2662).

Northern blot analyses. Total cellular RNA was isolated by the acid guanidinium thiocyanate-phenol-chloroform method (31). Total RNA (20 $\mu \mathrm{g})$ was separated by $1.0 \%$ agarose/ formaldehyde/MOPS gel electrophoresis, and transferred to a Hybond nylon membrane (Amersham). The cDNA probes for human amphiregulin and epiregulin were also prepared by RT-PCR using the following primers: amphiregulin 5':AGTGAGATTTCCCCTGTGAG [corresponding to nucleotides 391-410 (6)] and 3':CTCCTTCATATTTCCTG ACG (890-910), and epiregulin 5':GACAGTTCCCTATGC CAACT [1291-1310 (32)] and 3':GCTCCTTATGCAATAG CCCA (1992-2011). The hybridization was performed with ${ }^{32} \mathrm{P}-$ labeled probes generated by a random primed DNAlabeling kit (Amersham), and evaluated by autoradiography.

Cell proliferation assays. The number of cells was determined by a modification of the tetrazolium assay using MTT as a

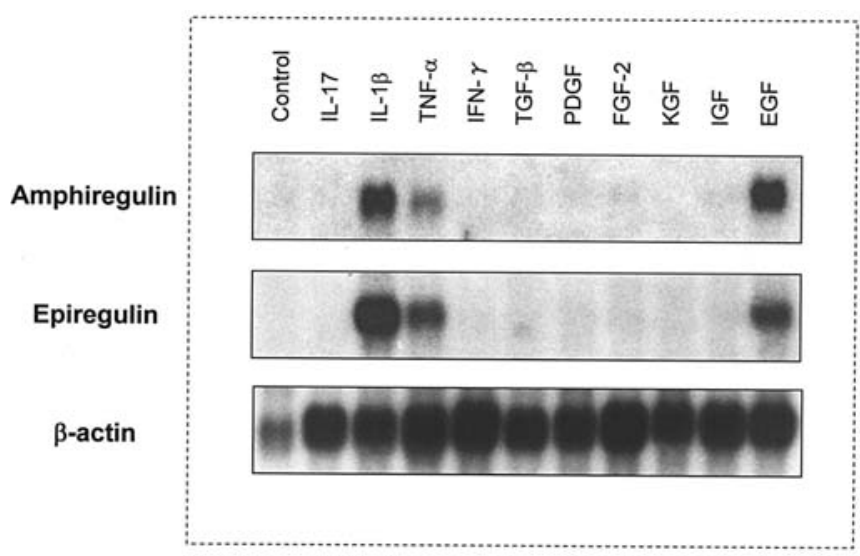

Figure 1. Effects of various cytokines and growth factors on mRNA expression of amphiregulin and epiregulin mRNA in human colonic SEMFs. Cells were incubated with each factor $(100 \mathrm{ng} / \mathrm{ml})$ for $12 \mathrm{~h}$, and total RNA was extracted. The mRNA expression for amphiregulin and epiregulin was assessed by Northern blotting.

substrate (33). Colonic SEMFs were seeded at a density of $3 \times 10^{4}$ cells per well in 96-well cell culture plates. Cells were exposed to amphiregulin, epiregulin or EGF. Cells were incubated for predetermined times, and then $50 \mu 1$ of PBS containing $0.5 \mathrm{mg} / \mathrm{ml} \mathrm{MTT} \mathrm{was} \mathrm{added} \mathrm{to} \mathrm{each} \mathrm{well.} \mathrm{After} \mathrm{a}$ 4-h incubation, $100 \mu \mathrm{l}$ of $0.04 \mathrm{~N} \mathrm{HCl}$ in isopropanol was added and mixed thoroughly. The absorbance in each well was read at $550 \mathrm{~nm}$ by a microplatereader. The cell number was expressed as a percentage relative to the cell number of controls incubated with medium alone.

Statistical analyses. Data are expressed as means \pm SD. Statistical significance of changes were determined with unpaired Student's t-test. Differences resulting in P-values $<0.01$ were considered significant.

\section{Results}

Effects of cytokines and growth factors on amphiregulin and epiregulin mRNA expression. Cells were stimulated with each factor $(100 \mathrm{ng} / \mathrm{ml})$ for $12 \mathrm{~h}$, and the mRNA expression for amphiregulin and epiregulin was evaluated by Northern blotting. As shown in Fig. 1, mRNA expression of amphiregulin and epiregulin was not detected in unstimulated SEMFs. IL-1ß, TNF- $\alpha$, and EGF induced a marked increase in this mRNA expression.

Effects of $I L-1 \beta, T N F-\alpha$, and EGF on amphiregulin and epiregulin $m R N A$ expression. Colonic SEMFs were incubated for $12 \mathrm{~h}$ with increasing concentrations of IL-1ß, TNF- $\alpha$ and EGF, and amphiregulin and epiregulin mRNA expression patterns were analyzed by Northern blotting. As shown in Fig. 2, IL-1ß dose-dependently induced amphiregulin and epiregulin mRNA expression. The effect of IL-1ß was detected at as low as $0.1 \mathrm{ng} / \mathrm{ml}$, and reached a maximum at $10 \mathrm{ng} / \mathrm{ml}$. TNF- $\alpha$ and EGF also induced a dose-dependent increase in amphiregulin and epiregulin mRNA expression (Fig. 2). The effects of TNF- $\alpha$ and EGF were detected at as low as $0.1 \mathrm{ng} / \mathrm{ml}$, and reached a maximum at $100 \mathrm{ng} / \mathrm{ml}$. 


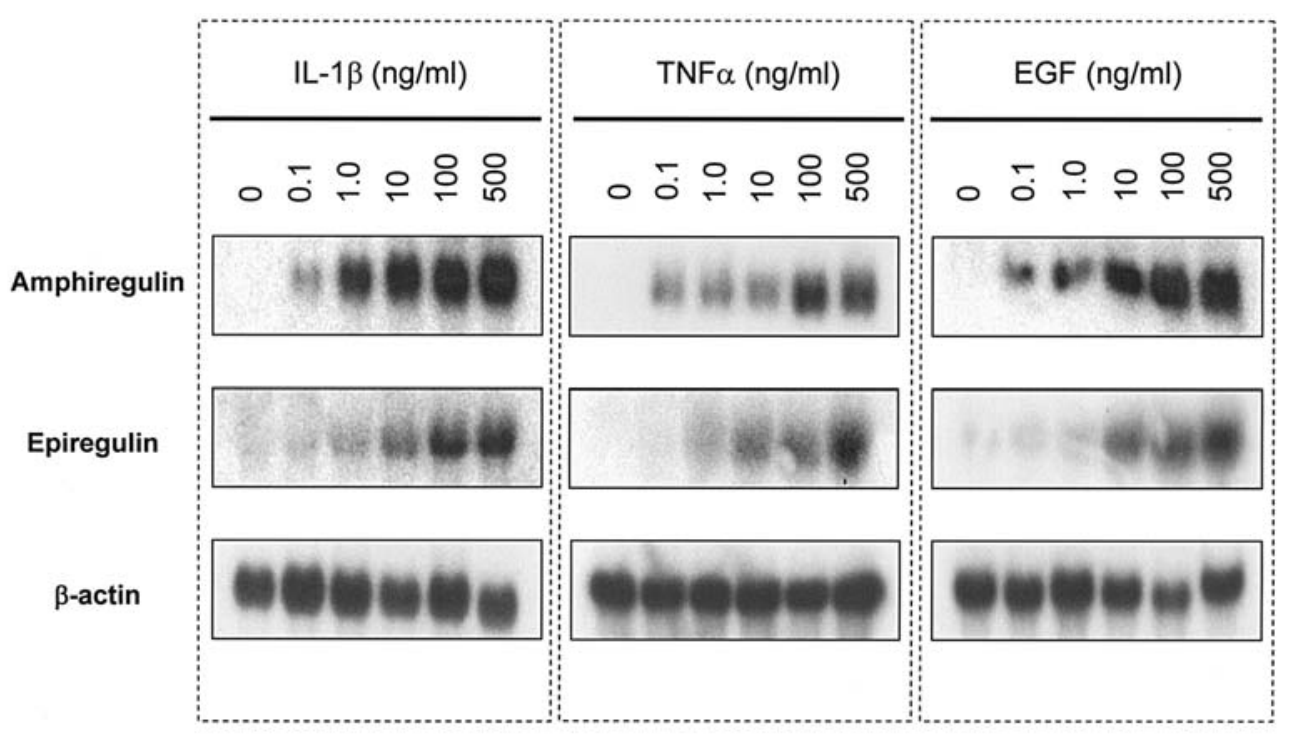

Figure 2. Induction of amphiregulin and epiregulin mRNAs in colonic SEMFs. Cells were stimulated for $12 \mathrm{~h}$ with various concentrations of IL-1ß, TNF- $\alpha$, and EGF. The mRNA expression for amphiregulin and epiregulin was analyzed by Northern blotting.

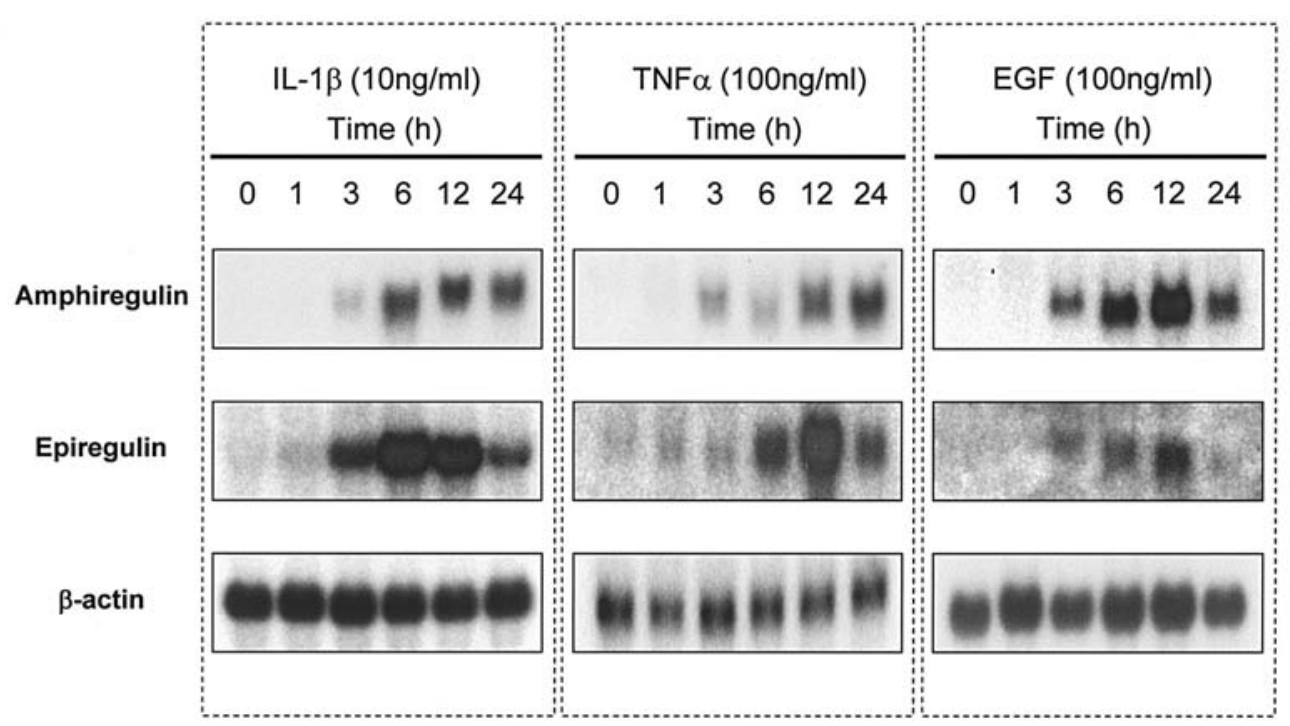

Figure 3. Kinetics of amphiregulin and epiregulin mRNA expression in colonic SEMFs. Cells were stimulated with IL-1ß (10 ng/ml), TNF- $\alpha$ (100 ng/ml), and EGF (100 ng/ml), and expression of amphiregulin and epiregulin mRNAs was sequentially determined by Northern blotting.

Kinetics of amphiregulin and epiregulin mRNA expression were evaluated (Fig. 3). Cells were stimulated with IL-1ß $(10 \mathrm{ng} / \mathrm{ml}), \mathrm{TNF}-\alpha(100 \mathrm{ng} / \mathrm{ml})$ or EGF $(100 \mathrm{ng} / \mathrm{ml})$, and the sequential changes in mRNA expression were determined by Northern blotting. IL- $1 \beta$ induced a rapid increase in the accumulation of amphiregulin and epiregulin mRNA, which reached a maximum at $6 \mathrm{~h}$ after stimulation. Thereafter, the induced amphiregulin mRNA level decreased gradually. Kinetics revealed that TNF- $\alpha$ and EGF-induced amphiregulin and epiregulin mRNA expression reached $12 \mathrm{~h}$ after stimulation (Fig. 3), which also gradually decreased.

Amphiregulin and epiregulin protein secretion. Colonic SEMFs were stimulated for $48 \mathrm{~h}$, and amphiregulin and epiregulin secretion was analyzed by immunoprecipitation and
Western blotting. As shown in Fig. 4, the addition of IL-1ß, TNF- $\alpha$, and EGF induced amphiregulin or epiregulin protein secretion. In previous reports, various soluble forms of amphiregulin (9.5-10, 28-30, 35, and 55-60 kDa) have been identified in several cell types $(5,6)$. In this study, amphiregulin was detected as one band at 9.5-10 kDa. Epiregulin secretion was also induced by the addition of IL-1ß, TNF- $\alpha$, and EGF. Epiregulin was detected as a band at $5 \mathrm{kD}$, which is compatible with previous reports (15).

Trophic effects of amphiregulin and epiregulin on SEMF proliferation. Since amphiregulin and epiregulin have been reported to stimulate proliferation of mesenchymal cells, we tested how these growth factors modulate colonic SEMF proliferation. Colonic SEMFs were cultured with various 


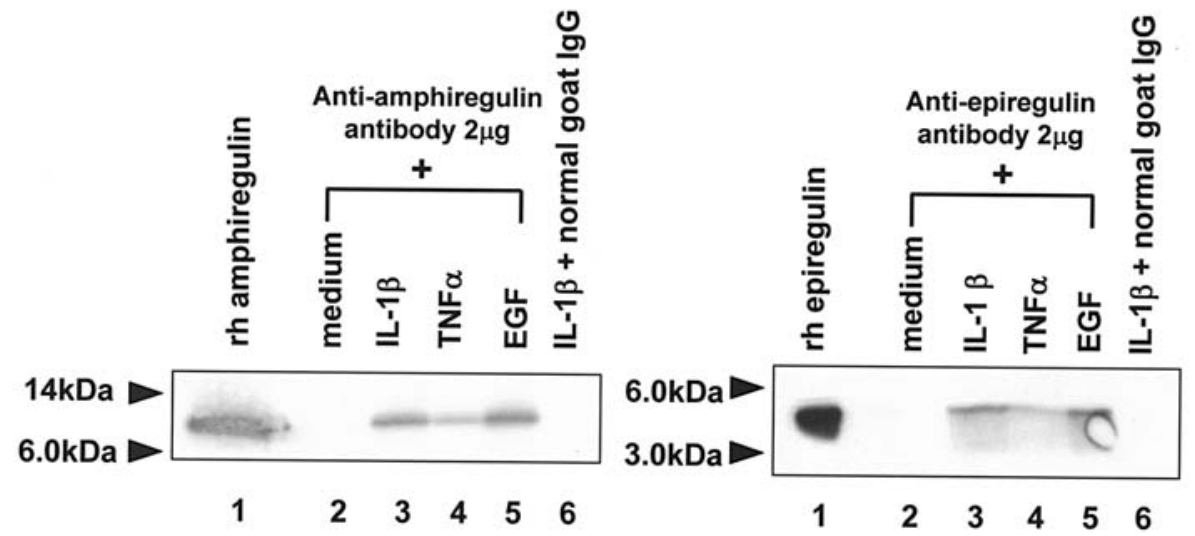

Figure 4. Amphiregulin and epiregulin secretion in colonic SEMFs. Cells were incubated for $48 \mathrm{~h}$ with IL-1ß (10 ng/ml), TNF- $\alpha$ (100 ng/ml), or EGF (100 ng/ml), and then amphiregulin and/or epiregulin proteins in supernatants were immunoprecipitated and analyzed by Western blotting. (A) Lane 1, recombinant amphiregulin (10 ng); lane 2, medium alone; lane 3, IL-1ß; lane 4, TNF- $\alpha$; lane 5, EGF; and lane 6, precipitated with normal rabbit IgG. (B) Lane 1, recombinant epiregulin (10 ng); lane 2, medium alone; lane 3, IL-18; lane 4, TNF- $\alpha$; lane 5, EGF; and lane 6, precipitated with normal rabbit IgG.

\section{(A)}

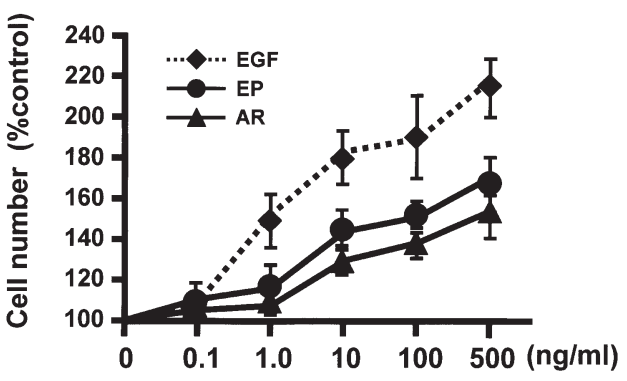

(B)

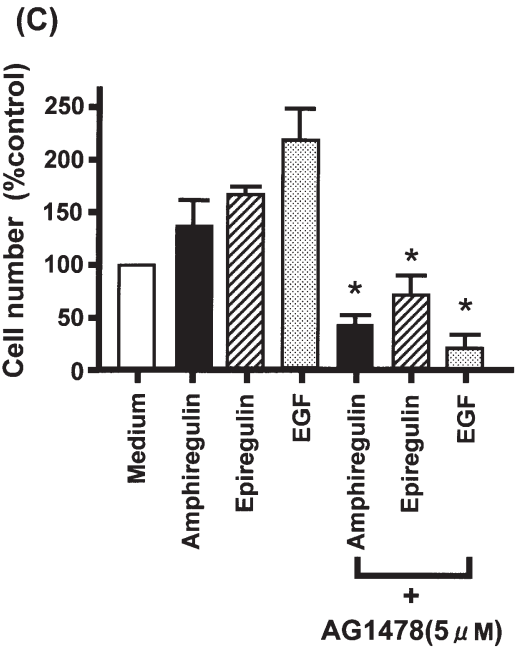

Figure 5. Effects of amphiregulin, epiregulin and EGF on proliferation of intestinal SEMFs. (A) Cells were incubated with increasing concentrations of recombinant amphiregulin, epiregulin, EGF for 8 days and total viable cell numbers were assessed by MTT assays. Data represent means \pm SD ( $=3$ ). (B) Cells were incubated with amphiregulin $(100 \mathrm{ng} / \mathrm{ml})$, epiregulin $(100 \mathrm{ng} / \mathrm{ml})$ or EGF $(100 \mathrm{ng} / \mathrm{ml})$, and total viable cell numbers were sequentially assessed by MTT assay. Data represent means \pm SD $(\mathrm{n}=3)$. (C) Cells were treated with amphiregulin $(100 \mathrm{ng} / \mathrm{ml})$, epiregulin $(100 \mathrm{ng} / \mathrm{ml}) \mathrm{or} \mathrm{EGF}(100 \mathrm{ng} / \mathrm{ml})$ in the presence or absence of AG1478 $(5 \mu \mathrm{M})$ for 8 days. Total viable cell numbers were assessed by MTT assays. Each column represents the mean of three independent experiments. Data represent means $\pm \mathrm{SD}(\mathrm{n}=4)$. ${ }^{*} \mathrm{P}<0.01$

concentrations of amphiregulin, epiregulin, and EGF for 8 days, and cell proliferation was analyzed by MTT assays (Fig. 5). These growth factors stimulated an increase in the cell number in a dose-dependent manner (Fig. 5A). Amphiregulin, epiregulin and EGF promoted the proliferation of colonic SEMFs up to day 8 (Fig. 5B). As shown in Fig. 5C, these effects were significantly inhibited by the addition of AG1478, a specific inhibitor of EGFR tyrosine kinase (34), suggesting that trophic effects of amphiregulin and epiregulin as well as EGF are mediated through EGFR-mediated signalling pathways.

It has been reported that amphiregulin and epiregulin exert their biological effects through the ERBB receptor family including EGFR, ERBB2, ERBB3 and ERBB4 $(1,35,36)$. To confirm the expression of these receptor subunits in colonic SEMFs, we performed RT-PCR analyses. As shown in Fig. 6, mRNA expression for EGFR, ERBB2, ERBB3, and ERBB4 was detected in colonic SEMFs.

Autocrine induction of amphiregulin and epiregulin $m R N A$ expression. Previously, amphiregulin stimulation has been reported to induce amphiregulin expression in bronchial epithelial cells (13). Based on this report, we tested similar responses in colonic SEMFs. As shown in Fig. 7, amphiregulin induced a rapid increase in the accumulation of amphiregulin mRNA within $3 \mathrm{~h}$ after stimulation. Similarly, epiregulin 


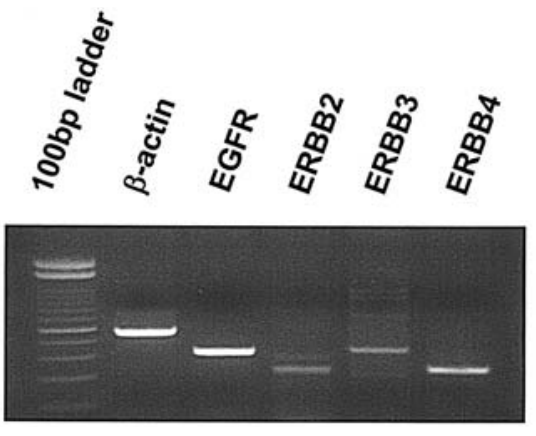

Figure 6. Reverse transcription-polymerase chain reaction (RT-PCR) analyses for mRNA expression of the EGF receptor family. Total cellular RNA was extracted from unstimulated cells, and the mRNA expression was analyzed by means of RT-PCR.

induced a rapid accumulation of epiregulin mRNA. The aforementioned observations suggest that amphiregulin and epiregulin exert biological effects on SEMFs through an autocrine fashion.

To confirm this possibility of autocrine regulation, we analyzed how AG1478 modulates the effects of IL-1ß and TNF- $\alpha$ as well as those of EGF. As shown in Fig. 8, AG1478 completely blocked EGF- and amphiregulin-induced amphiregulin mRNA expression. IL-1ß- and/or TNF- $\alpha$-induced amphiregulin mRNA expression was partially blocked by AG1478. Similarly, the effects of IL-1ß and TNF- $\alpha$ on epiregulin mRNA expression were partially blocked by AG1478, suggesting that EGFR-mediated responses might be involved in the responses induced by IL-1ß and TNF- $\alpha$.

\section{Discussion}

This study shows that among various cytokines and growth factors, IL-1ß, TNF- $\alpha$ and EGF specifically induce

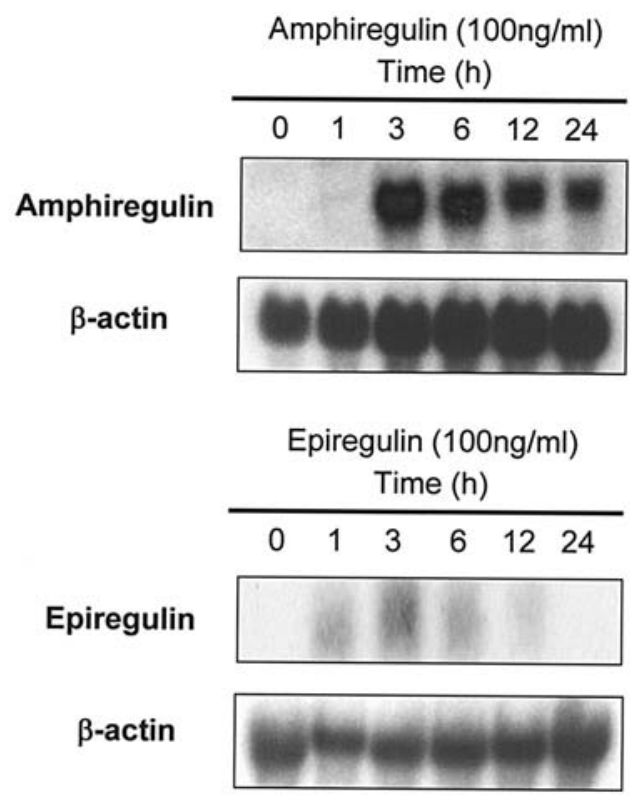

Figure 7. Effects of amphiregulin on amphiregulin mRNA expression (upper) and those of epiregulin on epiregulin mRNA expression (lower). Cells were incubated with amphiregulin $(100 \mathrm{ng} / \mathrm{ml})$ or epiregulin $(100 \mathrm{ng} / \mathrm{ml})$, and mRNA expression for each growth factor was analyzed by Northern blotting.

amphiregulin and epiregulin expression in human colonic SEMFs. To our knowledge, EGF-induced amphiregulin and epiregulin expression has not been reported in other cell types. Furthermore, amphiregulin and epiregulin exert their biological actions through an autocrine fashion. These observations suggest that colonic SEMFs may be a local source of amphiregulin and epiregulin, and that these phenomena may be important mechanisms controlling mucosal proliferation in healthy and diseased colons.
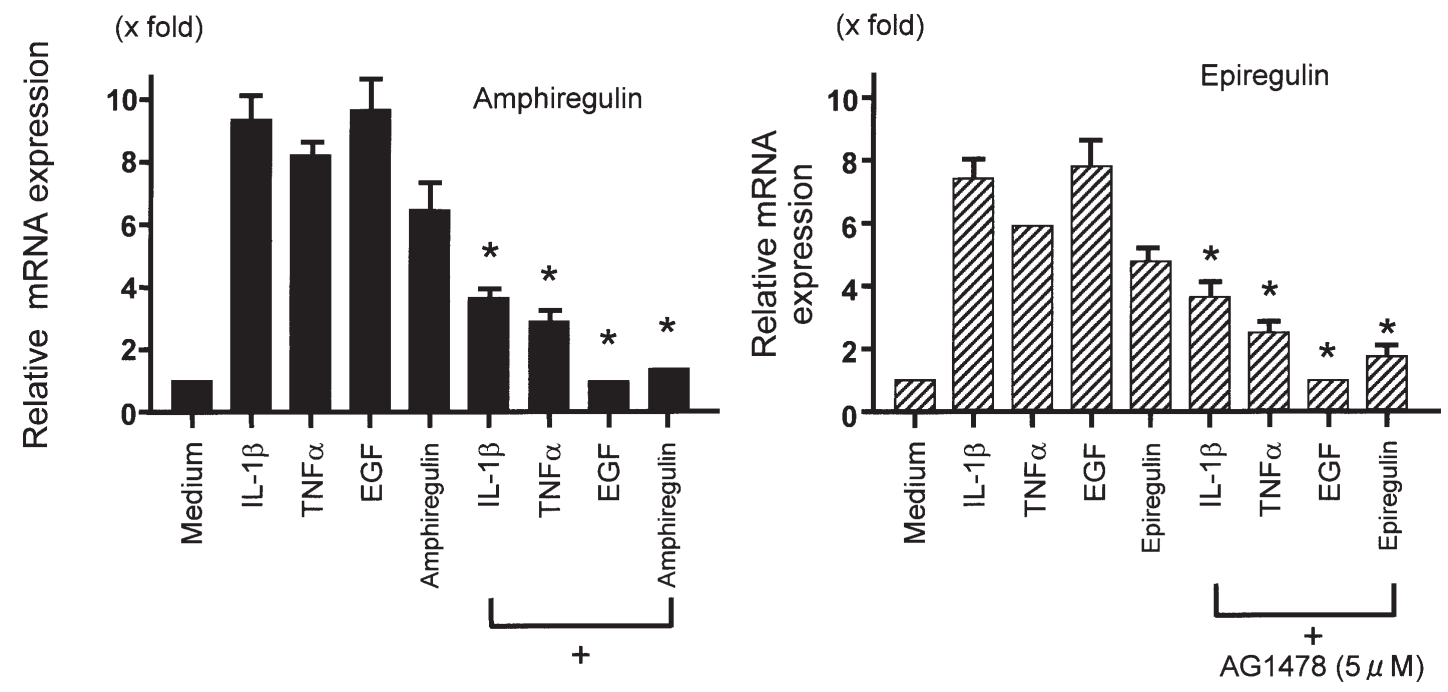

Figure 8. Effects of the EGFR tyrosine kinase inhibitor, AG1478, on mRNA expression for amphiregulin (A) and epiregulin (B). Cells were stimulated with IL-1ß $(10 \mathrm{ng} / \mathrm{ml}), \mathrm{TNF}-\alpha(100 \mathrm{ng} / \mathrm{ml})$, EGF (100 ng/ml), amphiregulin $(100 \mathrm{ng} / \mathrm{ml})$ or epiregulin $(100 \mathrm{ng} / \mathrm{ml})$ in the presence or absence of AG1478. The total RNA was then extracted, and Northern blotting was performed. The radioactivity of each band was determined from an Instant Imager ${ }^{\mathrm{TM}}$ Electronic Autoradiography system model (Packerd). Each amphiregulin or epiregulin mRNA value was standardized by an internal control for $\beta$-actin mRNA. Data were converted to relative expression to the value of medium alone. Data represent means $\pm \mathrm{SD}(\mathrm{n}=4)$. ${ }^{*} \mathrm{P}<0.01$. 
The proinflammatory cytokines, IL- $1 \beta$ and $\mathrm{TNF}-\alpha$, are representative proinflammatory cytokines that share several biological functions. Both cytokines promote inflammatory responses, regulate aspects of cellular immunity and are important in host defense against infection. IL- $1 \beta$ and TNF- $\alpha$ are produced by monocytes/macrophages and epithelial cells, and expression of these cytokines has been reported to be elevated in inflamed mucosa of inflammatory bowel disease (37). Based on these notions, the findings in this study suggest that some parts of proliferative responses in inflamed colonic mucosa are mediated by IL-1ß- and TNF- $\alpha$-induced amphiregulin and/or epiregulin. Furthermore, since amphiregulin (epiregulin) stimulated amphiregulin (epiregulin) expression, responses to IL- $1 \beta$ and TNF- $\alpha$ might be amplified in the inflamed mucosa through an autocrine fashion. It was previously reported that IL- $1 \beta$ and TNF- $\alpha$ stimulated the proliferation of intestinal SEMFs with a relatively longer incubation of $72 \mathrm{~h}(38,39)$. The proliferation of intestinal SEMFs may be explained by indirect effects of amphiregulin and epiregulin induced by IL- $1 \beta$ and TNF- $\alpha$. Amphiregulin and epiregulin are stimulators of proliferation of epithelial cells as well as mesenchymal cells, it is likely that proinflammatory cytokines such as IL- $1 \beta$ and TNF- $\alpha$ may play an important role in the process of tissue remodeling and wound healing through the induction of amphiregulin and epiregulin in intestinal mucosa.

EGF is a 6,000-Da polypeptide hormone, and exists in external secretions in the gastrointestinal tract (40). Previous studies demonstrated that EGF is a potent stimulator of proliferation of epithelial and mesenchymal cells, and suggested that EGF promotes repair processes in the inflamed mucosa of the intestine. For example, EGF treatments enhance resolutions of tri-nitrobenzenesulfonic acid-induced colitis in rats (41). Clinically, EGF enemas are effective for active distal ulcerative colitis (42). In this study, we found that among several growth factors EGF specifically induced amphiregulin and epiregulin expression in colonic SEMFs, suggesting that trophic effects of EGF in the colonic mucosa may be partially mediated by SEMF-derived amphiregulin and epiregulin induced by EGF. It is likely that EGF coordinates with proinflammatory cytokines to promote tissue repair processes via induction of amphiregulin and epiregulin.

EGF has been known to exert its trophic effects via the tyrosine kinase pathway through phosphorylation of EGF receptors (EGFRs) (1). In this study, we identified the four EGFRs in human colonic SEMFs, and demonstrated that AG-1478, a specific inhibitor of EGFR tyrosine kinases, markedly blocked EGF-induced amphiregulin and epiregulin mRNA expression in colonic SEMFs. The aforementioned result indicates that in colonic SEMFs phosphorylation of EGFR tyrosine kinase is actually involved in mechanisms underlying EGF-induced amphiregulin and epiregulin induction.

AG1478 partially blocked IL-1ß- and TNF- $\alpha$-induced mRNA expression for amphiregulin and epiregulin in colonic SEMFs. Since amphiregulin (epiregulin) is a potent inducer of amphiregulin (epiregulin) expression (Fig. 7), some parts of the effects of IL- $1 \beta$ and/or TNF- $\alpha$ on amphiregulin (epiregulin) expression may be indirectly mediated by EGFR phosphorylation in response to induced-amphiregulin and/or epiregulin.
Furthermore, it has previously been reported that IL-1ß and TNF- $\alpha$ induces phosphorylation of EGFR in CaCo-2 intestinal epithelial cells (43), suggesting a possibility that IL-1ß and/or TNF- $\alpha$ directly induce phosphorylation of EGFRs in colonic SEMFs.

In various cells, amphiregulin and epiregulin are bifunctional growth factors. To access the biological activity of amphiregulin and epiregulin in our system, we tested how these growth factors modulate proliferation of colonic SEMFs by means of MTT assays. Recombinant amphiregulin and epiregulin actually stimulated the proliferation of colonic SEMFs in a dose- and time-dependent manner. Combined with findings in previous studies that amphiregulin and epiregulin stimulate the proliferation of colonic epithelial cells $(10,11,17,44)$, amphiregulin and epiregulin play a crucial role in the process of wound healing through their action on both epithelial and mesenchymal cells in the intestine. The hypothesis may be supported by the previous reports which indicate that mice deficient in EGFRs showed an increased susceptibility to DSS-induced colitis $(17,45)$.

In conclusion, this study demonstrates that amphiregulin and epiregulin are expressed by human colonic SEMFs. Colonic SEMFs may play an important role in promoting repair processes following mucosal injury via amphiregulin and epiregulin expression.

\section{References}

1. Yarden Y and Sliwkowski MX: Untangling the ErbB signalling network. Nat Rev Mol Cell Biol 2: 127-137, 2001.

2. Chowdhury A, Fukuda R and Fukumoto S: Growth factor mRNA expression in normal colorectal mucosa and in uninvolved mucosa from ulcerative colitis patients. J Gastroenterol 31: 353-360, 1996.

3. Tarnawski AS and Jones MK: The role of epidermal growth factor (EGF) and its receptor in mucosal protection, adaptation to injury, and ulcer healing: involvement of EGF-R signal transduction pathways. J Clin Gastroenterol 27: 12-20, 1998.

4. Beck PL and Podolsky DK: Growth factors in inflammatory bowel disease. Inflamm Bowel Dis 5: 44-60, 1999.

5. Shoyab M, McDonald VL, Bradley JG and Todaro GJ: Amphiregulin: bifunctional growth-modulating glycoprotein produced by the phorbol 12-myristate 13-acetate-treated human breast adenocarcinoma cell line MCF-7. Proc Natl Acad Sci USA 85: 6528-6532, 1988.

6. Plowman GD, Green JM, McDonald VL, Neubauer MG, Disteche CM, Todaro GJ and Shoyab M: The amphiregulin gene encodes a novel epidermal growth factor-related protein with tumor-inhibitory activity. Mol Cell Biol 10: 1969-1981, 1990.

7. Normanno N, Selvam MP, Qi CF, Saeki T, Johnson G, Kim N, Ciardiello F, Shoyab M, Plowman G, Brandt R, Todaro G and Salmon DS: Amphiregulin as an autocrine growth factor for c-Ha-ras- and c-erbB-2-transformed human mammary epithelial cells. Proc Natl Acad Sci USA 91: 2790-2794, 1994.

8. Piepkorn M, Lo C and Plowman G: Amphiregulin-dependent proliferation of cultured human keratinocytes: autocrine growth, the effects of exogenous recombinant cytokine, and apparent requirement for heparin-like glycosaminoglycans. J Cell Physiol 159: 114-120, 1994

9. Chu EK, Foley JS, Cheng J, Patel AS, Drazen JM and Tschumperlin DJ: Bronchial epithelial compression regulates epidermal growth factor receptor family ligand expression in an autocrine manner. Am J Respir Cell Mol Biol 32: 373-380, 2005.

10. Johnson GR, Saeki T, Gordon AW, Shoyab M, Salomon DS and Stromberg K: Autocrine action of amphiregulin in a colon carcinoma cell line and immunocytochemical localization of amphiregulin in human colon. J Cell Biol 118: 741-751, 1992.

11. Damstrup L, Kuwada SK, Dempsey PJ, Brown CL, Hawkey CJ, Poulsen HS, Wiley HS and Coffey RJ Jr: Amphiregulin acts as an autocrine growth factor in two human polarizing colon cancer lines that exhibit domain selective EGF receptor mitogenesis. Br J Cancer 80: 1012-1019, 1999. 
12. Beales IL: Gastrin and interleukin-1beta stimulate growth factor secretion from cultured rabbit gastric parietal cells. Life Sci 75: 2983-2995, 2004.

13. Toyoda H, Komurasaki T, Uchida D, Takayama Y, Isobe T, Okuyama $\mathrm{T}$ and Hanada $\mathrm{K}$ : Molecular cloning of mouse epiregulin, a novel epidermal growth factor-related protein, expressed in the early stage of development. FEBS Lett 377 : 403-407, 1995.

14. Toyoda H, Komurasaki T, Uchida D, Takayama Y, Isobe T, Okuyama T and Hanada K: Epiregulin. A novel epidermal growth factor with mitogenic activity for rat primary hepatocytes. J Biol Chem 270: 7495-7500, 1995.

15. Shirakata Y, Komurasaki T, Toyoda H, Hanakawa Y, Yamasaki K, Tokumaru S, Sayama K and Hashimoto K: Epiregulin, a novel member of the epidermal growth factor family, is an autocrine growth factor in normal human keratinocytes. J Biol Chem 275: 5748-5753, 2000.

16. Takahashi M, Hayashi K, Yoshida K, Ohkawa Y, Komurasaki T and Kitabatake A: Epiregulin as a major autocrine/paracrine factor released from ERK- and p38MAPK-activated vascular smooth muscle cells. Circulation 108: 2524-2529, 2003.

17. Lee D, Pearsall RS, Das S, Dey SK, Godfrey VL and Threadgill DW: Epiregulin is not essential for development of intestinal tumors but is required for protection from intestinal damage. Mol Cell Biol 24: 8907-8916, 2004.

18. Mahida YR, Beltinger J, Makh S, Goke M, Gray T, Podolsky DK and Howkey CJ: Adult human colonic subepithelial myofibroblasts express extracellular matrix proteins and cyclooxygenase-1 and -2. Am J Physiol 273: 1341-1348, 1997.

19. Powell DW, Mifflin RC, Valentich JD, Crowe SE, Saada JI and West AB: Myofibroblasts. I. Paracrine cells important in health and disease. Am J Physiol 277: 1-9, 1999.

20. Powell DW, Mifflin RC, Valentich JD, Crowe SE, Saada JI and West AB: Myofibroblasts. II. Intestinal subepithelial myofibroblasts. Am J Physiol 277: 183-201, 1999.

21. Andoh A, Zhang Z, Inatomi O, Fujino S, Deguchi Y, Araki Y, Tsujikawa T, Kitoh K, Kin-Mitsuyama S, Takayanagi A, Shimizu N and Fujiyama Y: Interleukin-22, a member of the IL-10 subfamily, induces inflammatory responses in colonic subepithelial myofibroblasts. Gastroenterology 129: 969-984, 2005.

22. Yasui $\mathrm{H}$, Andoh A, Bamba S, Inatomi O, Ishida $\mathrm{H}$ and Fujiyama $\mathrm{Y}$ : Role of fibroblast growth factor-2 in the expression of matrix metalloproteinases and tissue inhibitors of metalloproteinases in human intestinal myofibroblasts. Digestion 69: 34-44, 2004.

23. Bamba S, Andoh A, Yasui H, Araki Y, Bamba T, and Fujiyama Y: Matrix metalloproteinase-3 secretion from human colonic subepithelial myofibroblasts: role of interleukin-17. J Gastroenterol 38: 548-554, 2003.

24. Inatomi O, Andoh A, Kitamura K, Yasui H, Zhang Z and Fujiyama Y: Butyrate blocks interferon-gamma-inducible protein10 release in human intestinal subepithelial myofibroblasts. J Gastroenterol 40: 483-489, 2005.

25. Andoh A, Bamba S, Fujiyama Y, Brittan M and Wright NA: Colonic subepithelial myofibroblasts in mucosal inflammation and repair: contribution of bone marrow-derived stem cells to the gut regenerative response. J Gastroenterol 40: 1089-1099, 2005.

26. Andoh A, Fujiyama Y, Sumiyoshi K, Sakumoto H and Bamba T: Interleukin 4 acts as an inducer of decay-accelerating factor gene expression in human intestinal epithelial cells. Gastroenterology 111: 911-918, 1996.

27. Merlino GT, Ishii S, Whang-Peng J, Knutsen T, Xu YH, Clark AJ, Stratton RH, Wilson RK, Ma DP, Roe BA, Hunts JH, Shimizu N and Pastan I: Structure and localization of genes encoding aberrant and normal epidermal growth factor receptor RNAs from A431 human carcinoma cells. Mol Cell Biol 5: 1722-1734, 1985.

28. Coussens L, Yang-Feng TL, Liao YC, Chen E, Gray A, McGrath J, Seeburg PH, Libermann TA, Schlessinger J and Francke U: Tyrosine kinase receptor with extensive homology to EGF receptor shares chromosomal location with neu oncogene. Science 230: 1132-1139, 1985.
29. Plowman GD, Whitney GS, Neubauer MG, Green JM, McDonald VL, Todaro GJ and Shoyab M: Molecular cloning and expression of an additional epidermal growth factor receptorrelated gene. Proc Natl Acad Sci USA 87: 4905-4909, 1990.

30. Plowman GD, Culouscou JM, Whitney GS, Green JM, Carlton GW, Foy L, Neubauer MG and Shoyab M: Ligandspecific activation of HER4/p180erbB4, a fourth member of the epidermal growth factor receptor family. Proc Natl Acad Sci USA 90: 1746-1750, 1993.

31. Chomczynski P and Sacchi N: Single-step method of RNA isolation by acid guanidinium thiocyanate-phenol-chloroform extraction. Anal Biochem 162: 156-159, 1987.

32. Toyoda H, Komurasaki T, Uchida D and Morimoto S: Distribution of mRNA for human epiregulin, a differentially expressed member of the epidermal growth factor family. Biochem J 326: 69-75, 1997.

33. Mosmann T: Rapid colorimetric assay for cellular growth and survival: application to proliferation and cytotoxicity assays. J Immunol Methods 65: 55-63, 1983.

34. Fry DW, Kraker AJ, McMichael A, Ambroso LA, Nelson JM, Leopold WR, Conners RW and Bridges AJ: A specific inhibitor of the epidermal growth factor receptor tyrosine kinase. Science 265: 1093-1095, 1994.

35. Shelly M, Pinkas-Kramarski R, Guarino BC, Waterman H, Wang LM, Lyass L, Alimandi M, Kuo A, Bacus SS, Pierce JH, Andrews GC and Yarden Y: Epiregulin is a potent pan-ErbB ligand that preferentially activates heterodimeric receptor complexes. J Biol Chem 273: 10496-10505, 1998.

36. Kansra S, Stoll SW, Johnson JL and Elder JT: Autocrine extracellular signal-regulated kinase (ERK) activation in normal human keratinocytes: metalloproteinase-mediated release of amphiregulin triggers signaling from ErbB1 to ERK. Mol Biol Cell 15: 4299-4309, 2004.

37. Reinecker HC, Steffen M, Witthoeft T, Pflueger I, Schreiber S, MacDermott RP and Raedler A: Enhanced secretion of tumour necrosis factor-alpha, IL-6, and IL-1 beta by isolated lamina propria mononuclear cells from patients with ulcerative colitis and Crohn's disease. Clin Exp Immunol 94: 174-181, 1993.

38. Okuno T, Andoh A, Bamba S, Araki Y, Fujiyama Y, Fujimiya M, and Bamba T: Interleukin- $1 \beta$, and Tumor Necrosis Factor- $\alpha$ induce chemokine and matrix metalloproteinase gene expression in human colonic subepithelial myofibroblasts. Scand J Gastroenterol 37: 317-324, 2002.

39. Jobson TM, Billington CK and Hall IP: Regulation of proliferation of human colonic subepithelial myofibroblasts by mediators important in intestinal inflammation. J Clin Invest 101: 2650-2657, 1998.

40. Heitz PU, Kasper M, van Noorden S, Polak JM, Gregory H and Pearse AG: Immunohistochemical localisation of urogastrone to human duodenal and submandibular glands. Gut 19: 408-413, 1978.

41. Procaccino F, Reinshagen M, Hoffmann P, Zeeh JM, Lakshmanan J, McRoberts JA, Patel A, French S and Eysselein VE: Protective effect of epidermal growth factor in an experimental model of colitis in rats. Gastroenterology 107: 12-17, 1994

42. Sinha A, Nightingale J, West KP, Berlanga-Acosta $J$ and Playford RJ: Epidermal growth factor enemas with oral mesalamine for mild-to-moderate left-sided ulcerative colitis or proctitis. N Engl J Med 349: 350-357, 2003.

43. Murthy S, Mathur SN and Field FJ: Tumor necrosis factor-alpha and interleukin-1beta inhibit apolipoprotein B secretion in $\mathrm{CaCo}-2$ cells via the epidermal growth factor receptor signaling pathway. J Biol Chem 275: 9222-9229, 2000.

44. Baba I, Shirasawa S, Iwamoto R, Okumura K, Tsunoda T, Nishioka M, Fukuyama K, Yamamoto K, Mekada E and Sasazuki T: Involvement of deregulated epiregulin expression in tumorigenesis in vivo through activated Ki-Ras signaling pathway in human colon cancer cells. Cancer Res 60: 6886-6889, 2000.

45. Egger B, Procaccino F, Lakshmanan J, Reinshagen M, Hoffmann P, Zeeh JM, Lakshmanan J, McRoberts JA, Patel A, French S and Eysselein VE: Mice lacking transforming growth factor alpha have an increased susceptibility to dextran sulfateinduced colitis. Gastroenterology 113: 825-832, 1997. 